\title{
Monitoring of Some Strength Parameters in Handball
}

\author{
Jeton Havolli', Abedin Bahtiri', Bujar Begu', Arta Ibrani', Sabri Makolli \\ 'Universi College, Department of Physical Culture, Sport and Recreation, Prishtina, Kosovo
}

\begin{abstract}
Handball is a sport, which requires high physical preparation as well as technical and tactical skills. Being tough sport scrolled with multiple players, it has huge power requirements, as well as a certain level of intelligence for solving of complex situations in the game. The aim of this research was monitoring of some strength parameters. The sample of subjects consists of 14 handball players, members of Handball Club Pristina. Subjects were female, aged $20 \pm 2$ years old. The measurements were made during the training sessions, in the sports gym where they train, during the 2008/09 season, initial measurement was made in the first micro cycle of preparatory period, while the final measurement was done after the end of the championship.Paired T-test were calculated for in initial and final measurement. The majority of variables have no statistically significant differences, and this should have come as a result of inadequate dosage of training loads and lack of proper training program.
\end{abstract}

Key words: Handball players, female, strength, competition

\section{Introduction}

All Strength and conditioning experts around the world agree that, for time spent in the gym to have a positive impact on your sports performance, you must ensure the exercises you perform - and the way you perform them - are related to your sporting movements in competition (Jonathan, 2009). Morphological characteristics of the body and motor abilities certainly have a great influence on an outstanding performance in handball (Šibila, Mohrič, Pori, 2009). Modern handball team consists of intense and intermittent activities such as running, sprinting, jumping as well as fights between players (i.e. holding, pushing etc.) (Kvorning, 2006). Strength is one of the main skills in physical abilities (Bompa \& Karrera, 2005). One of the current tendencies is to introduce in the structure of the power training sessions specific "kinetic muscle chains" training elements, meant to improve the specific strength and power indices of the handball players (Acsinte, Alexandru, \& Milon, 2009).

Assessment of power and strength could be multidimensional. Strength, while having potentially multiple definitions, is probably best defined as "the maximum amount of force of a muscle or a group of muscles that can generate in a specific movement pattern at a specific velocity of movement (Knuttgen \& Kraemer, 1987; as cited in Reiman \& Manske, 2009). Handball consists of intensive game, swift (sprint), jump, decline, and "battles" within official rules of the game, and where permitted, that are catching, drawing, pushing and holding the opponent player. All these elements make the Handball very tough sport. The match shows who is stronger, faster, more stable, more powerful. So handball game requires players with high anthropometric parameters and with good motor skills likestrength, speed, coordination etc. Having in mind all these qualities that characterize the game of handball, the most important and sensitive element is programmingthe loads of exercise. In a sample of a research that is conducted with top handball woman players, indicates the great potential of development of motor skills during the preparatory period (Srhoj \& Rogulj, 2001). All this requires systematic and persistent work in selection and development of young handball players.

The purpose of this paper is monitoring of some strength parameters of handball during a competitive season in Women Handball Super League of Kosovo, by examining the impact of

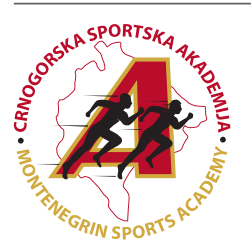

Correspondence: 
competitive strength in the outcome of competition, the objectives of the club were achieved by winning the National Championship, but real impact was shown on international level of competition. The Team that dominated against local teams, even up to 22 goals lead, failed to succeed in the qualifying competitions for the "Winners' Cup. Pristina team held only five minutes the pressure of stronger team from Holland, while the difference at the end of two matches reaches - 47 goals.

\section{Methods}

The sample of subject consists of 14 handball players, members of Handball Club Prishtina. Subjectswere female, aged $20 \pm 2$ years old. The measurements were made during the training sessions, in the sports gym where they train, during 2008/09 championship. The championship consists of two season, autumn season (September-November) and spring season (March-May). Initial measurement was made in the first micro cycleof preparatory period of spring season, while the final measurement was done after the end of the championship.The preparatory period consisted of 20 training sessions while a week consisted of 5 training sessions with 90 minutes for each session. Within spring season there were played 13 matches wich included the total number of 65 trainings.

Data analysis was performed using the Statistical Package for the Social Sciences (SPSS version 21.0). T-test were calcu- lated for same groups in initial and final measurement.

\section{Sample of variables}

- Throwing the medicine ball from standing position (MHTOPM)

- Long Throwing the ball after triple steps (MHT3HL)

- Bench press-20 kg (MB20KG)

- Hart rate befor the jump (PULQET)

- High jump after three steps with the ball in hand $5 \times 5$ jump (MK3HTO)

- Hart rate after jump (PULNGA)

\section{Results}

In Table 1 are shown results of descriptive statistics, mean and standard deviation of motor variables at initial and final measurement. Hendball players have improved result $(\mathrm{M}=161.14, \mathrm{SD}=29.99)$ in final measurement in comparison to the initial measurement $(\mathrm{M}=153.64, \mathrm{SD}=34.62)$ in variable (MHTOPM) throw of medicine ball in distance, for around 8 metres. Second best improvement is achieved in hitting on the goal after three steps, with about 4 metres (initial measurement $M=242.36, S D=60.66$, final Measurement $M=246.62$, $\mathrm{SD}=55.5)$. In other motor variables differences between two measurements are very small. Differences between two measurements will be tested with paired sample T-test.

Table 1. Descriptive statistics for motor variabiles initial and final measurement

\begin{tabular}{lccccccc}
\hline & \multicolumn{2}{c}{ Initial measurement } & \multicolumn{3}{c}{ Final measurement } \\
& $\mathrm{N}$ & Mean & Std. Deviation & & $\mathrm{N}$ & Mean & Std. Deviation \\
\hline MHTOPMI & 14 & 153.64 & 34.02 & MHTOPMF & 14 & 161.14 & 29.99 \\
MHT3HLI & 14 & 242.36 & 60.66 & MHT3HLF & 14 & 246.62 & 55.5 \\
MB2OKGI & 14 & 24.5 & 12.02 & MB20KGF & 14 & 25.24 & 10.77 \\
PULQETI & 14 & 78.71 & 6.28 & PULQETF & 14 & 80.9 & 6.12 \\
MK3HTOI & 14 & 240.79 & 13.13 & MK3HTOF & 14 & 241.9 & 14.63 \\
PULNGAI & 14 & 164.57 & 20.9 & PULNGAF & 14 & 167.52 & 18.89 \\
\hline
\end{tabular}

In Table 2 are shown the differences between the initial and final measurement. Initial measurement was made in the first micro cycle of preparatory period of spring season, while the final measurement was done after the end of the championship. According to the results (Table 2) there was found on- ly one variable where are significant differences between two measurements $p=.047$. The majority of variables have no statistically significant differences, and this should have come as a result of inadequate dosage of training loads and lack of proper training program.

Table 2. Paired Simple T-test

\begin{tabular}{lcccccc}
\hline & & Mean & Std. Deviation & T & df & \multicolumn{2}{c}{ Sig. (2-tailed) } \\
\hline Pair 1 & MHTOPMI-MHTOPMF & -.9071 & 1.6021 & -2.119 & 13 & .054 \\
Pair 2 & MHT3HLI-MHT3HLF & -.8143 & 1.6133 & -1.888 & 13 & .081 \\
Pair 3 & MB2OKGI-MB2OKGF & -2.7571 & 5.5438 & -1.861 & 13 & .086 \\
Pair 4 & PULQETI-PULQETF & 2.1430 & 3.6550 & 2.193 & 13 & .047 \\
Pair 5 & MK3HTOI-MK3HTOF & -7.3500 & 12.9065 & -2.131 & 13 & .053 \\
Pair 6 & PULNGAI-PULNGAF & -4.4290 & 16.9780 & -.976 & 13 & .347 \\
\hline
\end{tabular}

\section{Discussion}

The aim of this research was monitoring of some strength parametersof woman handball players of Super League of Kosovo. According to the results there was no any improvement of force parameters in handball women players between initial and final measurement even some progressive transformation was expected. The amount of training in the preparato- ry period, only 20 training, is not sufficient for achievement of workforce development at the desired level. Preparatory period with 41 trainings, can affect to achieve the force (Vuleta, Milanovic, \& Gruic, 2002). Also, the number of only five training sessions within a week was insufficient. Regarding mentioned training parameters the quality of teams in the Kosovo league is weak, as the club of this research has dominated all other 
teams of Super League and easilywon the National Championship, but has failed in international competitions.

Training loads by individual characteristics and specific skills in the game is a problem in itself that must have greater attention. Training loads should be done by adapting to the anthropometric status and motor abilities for each athlete individually.

There are many factors that could affect players' motivation as well as financial support plays important role in the level of responsibility, as well as coaching the game.

Therefore the recommendationsareto increase the number of exercises in the preparatory period as well as in competition phase, training program should be basedon anthropometric characteristics and motor abilities motivation will influence to increase responsibility and competition within the team.

We think that bytaking account on mentioned factors would short the difference in quality in international competitions.

\section{Acknowledgements}

The researchers are grateful to Abedin Bahtiri from the PristinaUniversi College for his contribution for organizing the measurements.

\section{Conflict of Interest}

The authors declare there are no conflict of interest.

Received: 17 March 2017| Accepted: 25 April 2017

\section{References}

Acsinte, A., Alexandru, E., \& Milon, A. (2009). Playing games motor skills development through aid exercises. The 5th FIEP European Congress, Nis, Serbia.

Bompa, T., \& Carrera, M. (2005). Periodization training for sports. London: Human Kinetics.

Jonathan, A. (2009). Strength Training new advances for maximum gains. London, P2P Publishing Ltd.

Knuttgen \& Kraemer (1987). Terminology and Measurement in Exercise Performance. Journal of Applied Sport Science Research, 1, 1-10.

Srhoj, V., \& Rogulj, N. (2001). Changes in the motor efficiency of top level handball players under the influence of programmed training in the preparation period. Proceeding book of 10th summer school for pedagogues in kinesiology, 80-82.

Kvorning, T. (2006). Strength Training in team Handball. 5th International Conference on Strength Training. Institut for Idrætog Biomekanik, Syddansk Universitet Denmark.

Vuleta, D., Milanovic, D., \& Gruic, I. (2002). Promene u pokazateljima kondicijske pripremljenosti vrhunskih rukometašica u pripremnom periodu. Proceedings Book of $3^{\text {rd }}$ International Scientific Conference (Opatia), 386-389.

Šibila, M., Mohrič, U., \& Pori, P. (2009). Razvojne razlike nekaterih motoričnih in morfoloških parametrih prieni generaciji rokometaši povprečni starosti 17, 19 in 21 let. Trener rokomet, 2, 5-10. 